\title{
Sub-bottom acoustic profiling as a remediation assessment tool for contaminated lakes
}

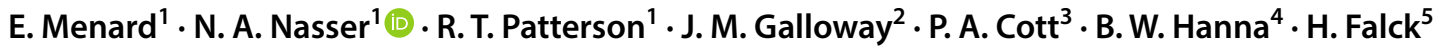

(c) Springer Nature Switzerland AG 2019

\begin{abstract}
Frame Lake, a small ( $88.4 \mathrm{ha})$, shallow ( $<6.5 \mathrm{~m}$ maximum depth), high-latitude lake found within the city limits of Yellowknife, Northwest Territories, Canada was selected due to the known legacy contamination of the lake's sediments to test the feasibility of using seismic sub-bottom profiling to estimate total volumes of heavy metal contaminated sediments in lacustrine environments. To ground-truth the sub-bottom profiling results, physical and ICP-MS analyses were carried out on freeze cores collected from Frame Lake's southern basin, and sedimentological marker beds and ${ }^{14} \mathrm{C}$ dating was used to chronologically constrain the lake depositional history. ICP-MS results showed high levels of arsenic contamination (up to $1538 \mathrm{\mu g} \mathrm{g}^{-1}$ ) in late twentieth-century lake sediments, which contrasts sharply with measured Holocene values that averaged only $16 \mu \mathrm{g} \mathrm{g}^{-1}(n=41, \pm 5.4 \mathrm{SD})$. The high arsenic content in lakebed sediments, which tends to be concentrated within specific horizons, results in distinct seismic reflectors within the acquired Sonar data. Stratigraphic horizons where arsenic was concentrated do not necessarily correlate with actual depositional events as changes in lake hydrology and redox conditions have resulted in remobilization and migration of arsenic in lake sediments. Direct GIS software comparison of core data against the sub-bottom profiler transect results permitted an interpolated lateral and vertical reconstruction of the distribution of variously contaminated sediments throughout the entire lake basin. Based on our analysis, a minimum of $\sim 230,000 \mathrm{~m}^{3}$ of contaminated sediments would need to be dredged from Frame Lake to achieve a minimum residual sediment arsenic concentration of $<150 \mu \mathrm{g} \mathrm{g}^{-1}$.
\end{abstract}

Keywords Lake sediment · Gold mining · Land-use-changes · Contamination · Arsenic · Sonar

\section{Introduction}

The City of Yellowknife, Northwest Territories, Canada, was founded in 1934 and thrived on the strength of major local gold mining operations, such as Giant Mine (1948-2004) and Con Mine (1938-1999). The Giant Mine was one of the longest-running and most productive gold mining operations in Canadian mining history, producing $\sim 7$ million ounces of gold through the mine's 56-year lifespan [1, 2].
Although profitable to mine, gold mineralization at the Giant Mine was closely associated with sulfides containing elevated concentrations of elements of environmental concern such as zinc, copper, lead and nickel, and especially arsenic (As) [3-5]. The refractory nature of the goldbearing ore in the Yellowknife area required the use of roasting to liberate gold from the hosting massive sulfides, primarily arsenopyrite. A by-product of this type of ore processing was the aerial release of $\sim 7400 \mathrm{~kg} /$ day of the

Electronic supplementary material The online version of this article (https://doi.org/10.1007/s42452-019-0588-z) contains supplementary material, which is available to authorized users.

$\square$ N. A. Nasser, nawaf.nasser@carleton.ca | ${ }^{1}$ Ottawa-Carleton Geoscience Centre and Department of Earth Sciences, Carleton University, 1125 Colonel By Dr., Ottawa, ON K1S 5B6, Canada. ${ }^{2}$ Geological Survey of Canada Calgary, Alberta T2L 2A7, Canada. ${ }^{3}$ Cott Environmental, Yellowknife, NT X1A 1R2, Canada. ${ }^{4}$ Wilfrid Laurier University, Waterloo, ON N2L 3C5, Canada. ${ }^{5}$ Northwest Territories Geological Survey, Yellowknife, NT X1A 2L9, Canada. 
highly toxic arsenic trioxide $\left(\mathrm{As}_{2} \mathrm{O}_{3}\right)$ during the early years of production (1948-1951), which was drastically reduced following the implementation of progressively more stringent emission controls in subsequent years $(\sim 16 \mathrm{~kg} / \mathrm{day})$ $[6,7]$. As part of the mine remediation process following the Giant Mine closure, an estimated 237,000 tonnes of $\mathrm{As}_{2} \mathrm{O}_{3}$ will be placed in cryostorage on site [8].

While gold mining and ore processing at Giant Mine and Con Mine officially ceased in 2004, the long-term environmental impact of these operations on the Yellowknife area persists to this day. The aerial release of $\mathrm{As}_{2} \mathrm{O}_{3}$ from stack emissions at the Con Mine and, especially, Giant Mine left behind a legacy of As contamination on the landscape (e.g., lakes, rivers, peatlands, and soil) and covered an area that extends to a radius of $\sim 30 \mathrm{~km}$ around the mine sites $[9,10]$. Lacustrine systems around mine sites, especially those located on Canadian Shield substrates such as in the Yellowknife area, are very susceptible to contaminant runoff from the catchment and direct air fall due to their low buffering capacity [9]. While efforts to remediate the Giant Mine site are currently underway (e.g., Giant Mine Remediation Project; [11]), areas off-site have received little or no attention.

Frame Lake, a highly As-contaminated lake within the Yellowknife city limits, was once an important community recreational area, with the popular McNiven bathing beach established by the 1950s [12]. By the early 1970's, however, Frame Lake had experienced a notable decline in lake health due to the impact of (1) historic gold-mininginduced As contamination; (2) the physical dumping of tailings and/or waste into the lake; (3) runoff of nutrientrich water from municipal development around the lake; and (4) changes in circulation and water throughput to the lake due to urban development-notably the construction of a causeway equipped with sluiceways at the lake outlet in 1975, though these sluiceways remain closed most of the year, as well as stormwater sewers that diverted a significant amount of inflow from entering the lake [13]. The cumulative impact of these changes led to the collapse and disappearance of fish populations in Frame Lake. Additionally, in the years following the building of the causeway, there was a concomitant increase in the production of aquatic macrophytes, and the rapid sediment accretion of a dark brown to black organic-rich sedimentary horizon, as the lake became progressively more eutrophic. Deposition of this variable thickness black sedimentary horizon has been associated with high levels of legacy contaminants, primarily As, from the mining operation of Giant Mine and Con Mine [13-15]. By the late 1970s, the steadily deteriorating environmental conditions within the lake resulted in a significant decline in the number of swimmers and beachgoers using McNiven Beach, which in turn led the city to eventually remove recreational facilities there. The beach itself has since disappeared, having been overgrown with grass [16].

There is a desire to rehabilitate Frame Lake so that it may once again become an important recreational area for residents and tourists alike. With the closure of the last operating gold mine in the area, the city of Yellowknife has refocused its economic development plan, with ecotourism being an important component [17]. Increased access to natural attractions such as local lakes, rivers, and wildlife is highly desired by visitors to the area. Frame Lake is in the middle of the City of Yellowknife, with City Hall, the Legislative Assembly of the NWT, and the Prince of Wales Northern Heritage Centre on its shore making rehabilitation of the lake also advantageous from a tourism and aesthetic perspective. Several remediation strategies for Frame Lake have been considered, including (1) dredging of contaminated sediments; (2) installation of aerators to permit fish to survive winter anoxia; (3) construction of storm-water management facilities at the inflows; and (4) opening of the sluiceways to increase the amount of outflow to increase lake water throughput [13]. If the lake is to be dredged, a significant amount of contaminated sediments would have to be removed. Removal of these sediments, which have accumulated since the early 1960s, has the potential of accelerating the overall remediation process, regardless of which other steps are pursued after dredging. In an effort to constrain the cost and feasibility of dredging the lake, a necessary first step is to map out the spatial extent and the thickness of the contaminated sediments within Frame Lake.

Dredging costs are largely associated with the amount of material required to be dredged (i.e., total volume) along with any subsequent treatment and/or disposal, which requires information on the concentration of contained contaminants. Although the analysis of sedimentary cores can provide fairly reliable baseline data to assist dredging efforts, collection of a number of cores sufficient to generate reliable baseline data may be cost-prohibitive. To provide cost-effective baseline data useful for determining the future dredging costs associated with remediation efforts in Frame Lake, an innovative, cost-effective, multidisciplinary approach was designed, where data derived from sub-bottom profiling, freeze and Glew cores, as well as geospatial interpolation, were together utilized to (1) assess the geochemical condition and spatiotemporal distribution of As-contaminated sediments within Frame Lake; and (2) estimate the thickness and volume of Ascontaminated sediments throughout the lake.

Improving the geoscience tools available to assess the nature and environmental impact of contaminated sediments in lakes is of considerable use to researchers and resource managers so that they can better and more cost effectively direct resources toward remediation efforts, 
and to better inform regulatory agencies and the concerned public.

\section{Regional setting}

Frame Lake $\left(62.454^{\circ} \mathrm{N},-114.390^{\circ} \mathrm{E}\right)$ is a subarctic lake within the Yellowknife Supergroup of the southern Slave structural province of the Canadian Shield (see $[2,18])$ in the central Northwest Territories, Canada (Fig. 1). Bedrock geology is mainly comprised of Archean meta-volcanic and meta-sedimentary rocks that are intruded by younger granitoids (see [19-21]).

Surficial sediments in the study area are primarily comprised of a thin ( $<2 \mathrm{~m}$ thick) discontinuous veneer of till and Glacial Lake McConnell sediments [22]. The till is comprised of a stony and loosely compacted matrixsupported diamicton [22]. Sediments derived from glacial Lake McConnell $(11,800-8300$ yBP), the remnants of which forms modern Great Slave Lake, Great Bear Lake, and Athabasca Lake basins, were laid down during deglaciation and are comprised of poorly to moderately sorted coarse to fine sand, silt, and clay that can be up to $20 \mathrm{~m}$ thick in some topographic lows [22-24]. Holocene peatlands are also common in the study region and can be $\geq 1 \mathrm{~m}$ thick in bogs and other low-lying wetlands [22].

The Yellowknife area has a continental subarctic climate with relatively cool, dry summers and even dryer, cold winters, a mean annual temperature of $-4.3^{\circ} \mathrm{C}$ and mean annual precipitation of only $288.6 \mathrm{~mm}$ [25]. July is characterized by mean daily temperature and precipitation of $17.0^{\circ} \mathrm{C}$ and $40.8 \mathrm{~mm}$ respectively, while mean

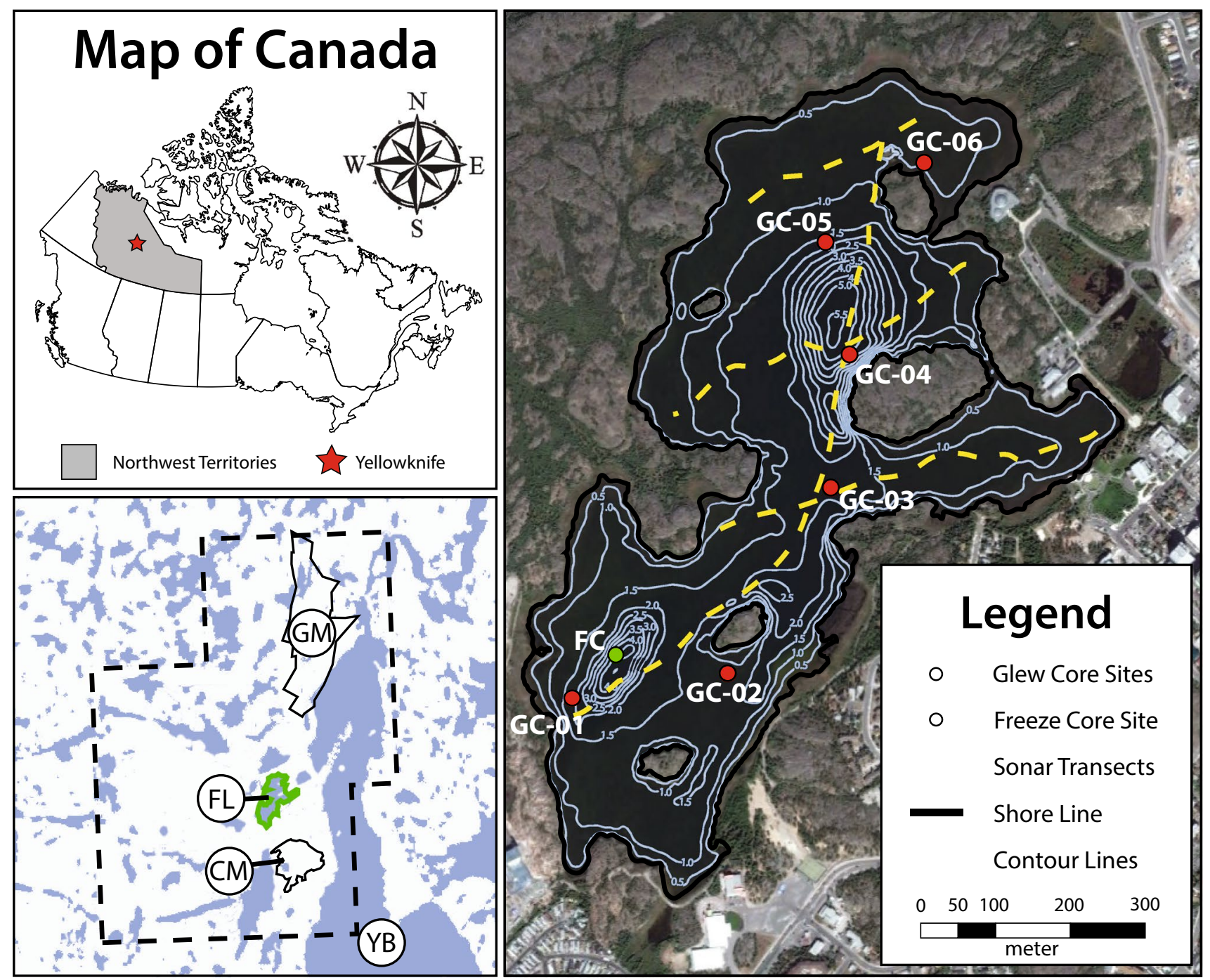

Fig. 1 Map showing the location of the study area marked by the red star (top left); regional view of the study area with the locations of Giant Mine (GM) and Con mine (CM), Frame Lake (FL) and Yel- lowknife bay (YB), City of Yellowknife (Municipal boundary line as dashed line; bottom left); Frame Lake, NWT, Canada (right). Modified after Gavel et al. [13] 
January values are $-25.6{ }^{\circ} \mathrm{C}$ and $14.3 \mathrm{~mm}$ [25]. The record summer maximum and winter minimum temperatures are separated by more than $80^{\circ} \mathrm{C}\left(32.5^{\circ} \mathrm{C}\right.$, July $1989 ;-51.2^{\circ} \mathrm{C}$ February 1947; [25]). Both mean daily temperatures and mean total precipitation have increased in recent years when comparing average mean daily temperatures and annual mean precipitation for the intervals 1961-1990 and $1981-2010\left(-5.2^{\circ} \mathrm{C}\right.$ vs. $-4.3^{\circ} \mathrm{C}, 267.3 \mathrm{~mm}$ vs. $288.6 \mathrm{~mm}$; $[25,26])$. Prevailing winds are from the east most of the year, with the exception of the summer months, June, July, and August, when they tend to be out of the south [25].

\subsection{Frame lake}

The overall morphology of lakes and rivers in the Yellowknife region are heavily influenced by the local topography and resistance to erosion of local bedrock, which was sculpted primarily by glacial scouring rather than by fluvial erosion [22]. Frame Lake has a surface area of 88.4 ha and is physiographically similar to many other lakes in the area. The lake has a maximum depth of $6.5 \mathrm{~m}$, with $\sim 54 \%$ of the surrounding $3.48 \mathrm{~km}^{2}$ catchment area being influenced in varying degrees by built infrastructure $[12,15]$. The area immediately around the lake is characterized by low relief terrain that is comprised mostly of bare rock outcrops with topographic lows infilled with glacial and glaciolacustrine sediments [22]. The lake's catchment in places supports vegetation, including conifers, paper birch and shrubs, as well as peat bogs, fens and marshes [22]. The oldest lake sediments are Lake McConnell deposits laid down immediately following post-glacial retreat of the Laurentide Ice Sheet, which transitioned to Ancestral Great Slave Lake sediments as the larger lake fractured into smaller water bodies. Frame Lake existed as an embayment of Ancestral Great Slave Lake until $~ 7000$ years BP when it slowly became isolated [27, 28]. Due to the low topographic relief, rocky terrain, and small amounts of precipitation in the area, sedimentation essentially ceased in the Frame Lake basin following early Holocene isolation, until $~ 1962$ when anthropogenic influences within the lake catchment resulted in a renewed, rapid sedimentary infill of the lake basin [13]. The present-day inflow of water to Frame Lake is mostly derived from sheet wash or from small ephemeral channels during rainfall events and snowmelt $[13,15]$. The sluice gate in a causeway on the lake's eastern shore controls most of the water outflow from the lake, though it remains closed most of the year [13].

\subsection{Lacustrine sedimentary As levels in the Yellowknife area}

Mean background concentrations of As in the sediments of Canadian lakes fall within the range of $2.5-10.7 \mu \mathrm{g} \mathrm{g}^{-1}$
$[29,30]$, but natural background levels in the Yellowknife area are far higher $\left(150 \mathrm{\mu g} \mathrm{g}^{-1}\right.$; [31]), mainly due to local bedrock geochemistry. Arsenic contamination in the immediate area around the Giant Mine has been as high as $20,400 \mathrm{Mg} \mathrm{L}^{-1}$ in surface waters downstream from a tailing pond in Baker's Creek [32]. Palmer et al. [9] found concentrations up to $646 \mathrm{\mu g} \mathrm{L}^{-1}$ in a study of 98 lakes, sampled in 2012 and 2014. Sediment samples in the region collected by Mudroch [3] had peak As concentrations of 890 and $2800 \mathrm{\mu g} \mathrm{g}^{-1}$ in Yellowknife Bay and Back Bay respectively, while a study by Mace [33] found peak As concentrations in surface sediment samples of up to $3821 \mu^{g^{-1}}$ in a tributary of Yellowknife Bay. Recent multi-lake studies in the Yellowknife region, which included Frame Lake, found maximum As concentrations in surface sediments from $155 \mu \mathrm{g} \mathrm{g}^{-1}$ to over $10,000 \mu^{-1} \mathrm{~g}^{-1}$ (i.e., exceeding instrumental detection limit; [8, 34, 35]). High levels of various contaminants have previously been measured in Frame Lake (e.g., As, Copper, Antimony, Uranium, Lead) with As levels ranging up to $1840 \mu \mathrm{g} \mathrm{g}^{-1}[13,14]$.

\section{Materials and methods}

\subsection{Research design and field work}

Core samples, water property data, side-scan sonar and sub-bottom profile data were collected from Frame Lake during two summer field seasons in 2012 and 2014. Three freeze cores were obtained from Frame Lake's southern basin in August 2012 and six Glew cores [35] were collected from throughout the lake in 2014 (Fig. 1). The Glew cores were logged and photographed on site to visually assess stratigraphic changes across the lake and provide ground-truth data for subsequent interpretation of the sub-bottom profile results. The freeze cores were obtained from the southern basin and included: (1) a single-faced freeze core (2012-1FR; $86 \mathrm{~cm}$ long) obtained from $4.1 \mathrm{~m}$ water depth (Fig. 1); (2) two double-faced freeze cores $(2012-2 F R F 1[60 \mathrm{~cm}]$ and $2012-2 F R F 2[60.4 \mathrm{~cm}])$ retrieved from a water depth of $4.6 \mathrm{~m}$. Freeze cores were more labor-intensive to collect than the Glew cores, but they preserved fine sedimentary structures at the soupy sediment-water interface, and were subsampled with a freeze core microtome at high resolution [36]. The freeze cores were cleaned, logged and photographed before being shipped frozen to Carleton University, where they were stored in a walk-in freezer at a temperature of $-20^{\circ} \mathrm{C}$ for subsequent analysis.

Details of the lake bottom and subsurface were obtained along 4 transects run across the lake during September of 2014 (Fig. 1) using a Lowrance HDS-8 sonar with StructureScan ${ }^{\mathrm{TM}}$ (model LSS-1). Sub-bottom profiling data 
was collected at a high wavelength frequency of $800 \mathrm{kHz}$, which was most suitable for discriminating details of the sediment-water interface and shallow subsurface reflectors in the relatively thin and soupy Frame Lake substrate [37]. Data files were saved in the .SL2 file format and were imported and subsequently processed using the SonarTRX software (v. 15.1.5601.14680), where the data could be visualized as a single crosscut through the sediment along the transect with a width equal to 0 .

\subsection{Laboratory work}

\subsubsection{Geochemical analysis and radiocarbon dating}

The top $60 \mathrm{~cm}$ of freeze core 2012-1FR was sub-sampled into 1-mm segments using a custom-made sledge microtome [36]. Sub-samples were subsequently recombined, when necessary, to meet minimum sample weight requirements for the Inductively Coupled Plasma Mass Spectrometry analysis (ICP-MS; minimum of $250 \mathrm{mg}$ dry weight) performed by ACME labs (Bureau Veritas Commodities Canada Ltd.) using the Aqua Regia digestion technique (AQ200 protocol; Online Resource 1). Core 2012-2FRF2 was sub-sampled into $0.5 \mathrm{~cm}$ segments from the top of the core down to $15 \mathrm{~cm}$ as well as a sub-sample from 19.5 to $20.5 \mathrm{~cm}$. Cores 2012-2FRF1 and 2012-1FR were also sub-sampled at various depths to confirm radiocarbon findings. Samples from core 2012-2FRF2 were submitted to the A. E. Lalonde AMS Laboratory, University of Ottawa, while those from 2012-2FRF1 and 2012-1FR were submitted to the 14 Chrono Centre, Queen's University, Belfast for radiocarbon analysis (Table 1 ).

\subsubsection{Sub-bottom profile analysis}

To assess the amount and temporal distribution of contaminated sediments, a preliminary analysis of the freeze core ICP-MS and sonar data was conducted to (1) assess the down-core variability of As concentrations; (2) identify stratigraphic units (i.e., layers) corresponding to certain As levels; and (3) determine whether identified stratigraphic units could be observed from the sonar data. The identified units were then measured (to the closest $0.5 \mathrm{~cm}$ ) along the sonar transects, using the Spectrum and/or Graytones colour scheme in the SonarTRX software, depending on the contrast of the sonar image at a given location. The layer thickness and GPS coordinates at 209 locations along four transects $(2 \pm 1 \mathrm{~cm}$, total length of $3378 \mathrm{~m})$ were recorded and were subsequently imported into ArcMap $^{\text {TM }}$ (v. 10.4.1; ArcGIS software by ESRI, Inc.) as a shapefile. A lake contour shapefile along with several data points near the shoreline were created, the latter of which was to simulate the tapering off of the fine-grained, highly contaminated particulates measured by the ICP-MS data in the freeze core near the shore.

\subsubsection{Interpolation, thickness and volume estimation of the contaminated horizon}

An Inverse Distance Weighted (IDW) interpolation was performed to estimate the thickness of the identified sediment layers (Fig. 5) using the GeoStatistical Analyst package in ArcMap. Given the density and distribution of the data, IDW was chosen for the task as it generated the best results compared to other tested interpolative techniques (e.g., kriging and spline). The identified layers were then combined to give the total thickness of highly contaminated sediment (As> $150 \mathrm{\mu g} \mathrm{g}^{-1}$ ) throughout Frame Lake, and the total volume of the contaminated sediment was calculated using the Surface Volume tool in ArcMap. The error of the total volume was calculated as $3.8 \%$, based on the measurement error and the mean sediment thickness.

\section{Results}

\subsection{Radiocarbon dating and other chronostratigraphic markers}

Thirty samples from the top $15-\mathrm{cm}$ of sediment from core 2012-2FRF2 yielded dateable material. High-resolution radiocarbon ${ }^{14} \mathrm{C}$ analysis of these samples yielded calibrated ages between 349 and 1233 yBP with multiple age reversals throughout the interval (Table 1). The sample between 2.5 and $3.0 \mathrm{~cm}$ did not return a date due to a lack of adequate dateable material. Although the general depositional history of the lake is known, these ${ }^{14} \mathrm{C}$ radiocarbon dates provide supporting evidence that these jumbled sediments were most likely of an allochthonous origin (e.g., old carbon-bearing sediments washed into the lake from the lake catchment; as rumored in the community, illegally dumped from elsewhere [see Sect. 5]). Additional dates acquired from cores 2012-2FRF1 and 2012-1FR showed similar age reversals in the top $15-\mathrm{cm}$ and midHolocene ages between 6749 and 8386 yBP from samples found at depths $>20-\mathrm{cm}$ (Table 1 ).

\subsection{Freeze- and Glew-core stratigraphy}

Stratigraphic analysis of freeze core 2012-1FR revealed three distinct stratigraphic units. The top unit (U1) comprises the uppermost $17 \mathrm{~cm}$ of the core and is characterized by very fine-grained, organic-rich, dark green to black sediments (Fig. 2). U1 was punctuated by three thin, conspicuous, light grey ash layers ( $2-3 \mathrm{~mm}$ each) deposited between 13 and $15 \mathrm{~cm}$ and had a sharp stratigraphic 
Table 1 Radiocardon data from top $15 \mathrm{~cm}$ Bulk sediment of freeze core 2012-2FRF2, as well as random samples and samples from further down core of freeze cores 20122FRF1 and 2012-1FR

\begin{tabular}{|c|c|c|c|c|c|}
\hline Lab ID & Depth range $(\mathrm{cm})$ & ${ }^{14} \mathrm{C}$ age $(\mathrm{BP}) \pm 1 \sigma$ & F14C & \pm & cal yBP \\
\hline UOC-0004 & $0.0-0.5$ & $405 \pm 20$ & 0.9508 & 0.0024 & $\begin{array}{l}452-511(89.0 \%) \\
335-349(6.4 \%)\end{array}$ \\
\hline UOC-0005 & $0.5-1.0$ & $591 \pm 19$ & 0.929 & 0.0022 & $\begin{array}{l}585-645(71.1 \%) \\
542-566(24.3 \%)\end{array}$ \\
\hline UOC-0006 & $1.0-1.5$ & $513 \pm 19$ & 0.9382 & 0.0023 & $510-546(95.4 \%)$ \\
\hline UOC-0007 & $1.5-2.0$ & $536 \pm 20$ & 0.9354 & 0.0023 & $\begin{array}{l}606-625(13.0 \%) \\
518-557(82.4 \%)\end{array}$ \\
\hline UOC-0008 & $2.0-2.5$ & $657 \pm 20$ & 0.9215 & 0.0022 & $\begin{array}{l}634-668(45.0 \%) \\
560-595(50.4 \%)\end{array}$ \\
\hline UOC-0009 & $2.5-3.0$ & $\mathrm{~N} / \mathrm{A}$ & N/A & $\mathrm{N} / \mathrm{A}$ & \\
\hline UOC-0010 & $3.0-3.5$ & $853 \pm 20$ & 0.8993 & 0.0022 & $\begin{array}{l}724-794(92.6 \%) \\
705-719(2.8 \%)\end{array}$ \\
\hline UOC-0011 & $3.5-4.0$ & $1044 \pm 21$ & 0.8781 & 0.0022 & 926-977 (95.4\%) \\
\hline UOC-0012 & $4.0-4.5$ & $1005 \pm 20$ & 0.8824 & 0.0022 & $\begin{array}{l}907-963(92.7 \%) \\
832-844(2.7 \%)\end{array}$ \\
\hline UOC-0013 & $4.5-5.0$ & $661 \pm 19$ & 0.9211 & 0.0021 & $\begin{array}{l}637-669(47.3 \%) \\
561-593(48.1 \%)\end{array}$ \\
\hline UOC-0014 & $5.0-5.5$ & $349 \pm 18$ & 0.9574 & 0.0022 & $\begin{array}{l}421-485(42.7 \%) \\
316-398(52.7 \%)\end{array}$ \\
\hline UOC-0015 & $5.5-6.0$ & $614 \pm 19$ & 0.9264 & 0.0022 & $551-654(95.4 \%$ \\
\hline UOC-0016 & $6.0-6.5$ & $788 \pm 21$ & 0.9065 & 0.0023 & 679-732 (95.4\%) \\
\hline UOC-0017 & $6.5-7.0$ & $373 \pm 19$ & 0.9546 & 0.0022 & $\begin{array}{l}428-500(66.9 \%) \\
326-375(28.5 \%)\end{array}$ \\
\hline UOC-0018 & $7.0-7.5$ & $1070 \pm 18$ & 0.8753 & 0.002 & $\begin{array}{l}1028-1049(13.0 \%) \\
931-1000(82.4 \%)\end{array}$ \\
\hline UOC-0019 & $7.5-8.0$ & $865 \pm 21$ & 0.8979 & 0.0024 & $\begin{array}{l}868-899(6.4 \%) \\
726-799(89.0 \%)\end{array}$ \\
\hline UOC-0020 & $8.0-8.5$ & $519 \pm 19$ & 0.9375 & 0.0022 & $\begin{array}{l}580-651(74.8 \%) \\
546-570(20.6 \%)\end{array}$ \\
\hline UOC-0021 & $8.5-9.0$ & $635 \pm 19$ & 0.924 & 0.0022 & $\begin{array}{l}626-661(38.2 \%) \\
556-604(57.2 \%)\end{array}$ \\
\hline UOC-0022 & $9.0-9.5$ & $955 \pm 21$ & 0.8879 & 0.0023 & $\begin{array}{l}891-928(28.9 \% \\
795-883(66.5 \%)\end{array}$ \\
\hline UOC-0023 & $9.5-10.0$ & $749 \pm 19$ & 0.911 & 0.0021 & $\begin{array}{l}719-721(0.6 \%) \\
665-704(94.8 \%)\end{array}$ \\
\hline UOC-0024 & $10.0-10.5$ & $945 \pm 19$ & 0.8891 & 0.0021 & 796-922 (95.4\%) \\
\hline UOC-0025 & $10.5-11.0$ & $1012 \pm 23$ & 0.8816 & 0.0025 & $\begin{array}{l}910-966(94.5 \%) \\
835-840(0.9 \%)\end{array}$ \\
\hline UOC-0026 & $11.0-11.5$ & $872 \pm 22$ & 0.8971 & 0.0025 & $\begin{array}{l}866-901(12.4 \%) \\
814-825(2.0 \%) \\
729-800(80.9 \%)\end{array}$ \\
\hline UOC-0027 & $11.5-12.0$ & $1056 \pm 19$ & 0.8768 & 0.0021 & $\begin{array}{l}1034-1045(3.1 \%) \\
927-983(92.3 \%)\end{array}$ \\
\hline UOC-0028 & $12.0-12.5$ & $846 \pm 20$ & 0.9001 & 0.0023 & $700-789$ (95.4\%) \\
\hline UOC-0029 & $12.5-13.0$ & $736 \pm 25$ & 0.9125 & 0.0028 & $\begin{array}{l}719-721(0.6 \%) \\
657-704(94.8 \%)\end{array}$ \\
\hline UOC-0030 & $13.0-13.5$ & $866 \pm 19$ & 0.8978 & 0.0021 & $\begin{array}{l}875-892(3.2 \%) \\
729-797(92.2 \%)\end{array}$ \\
\hline UOC-0031 & $13.5-14.0$ & $1123 \pm 64$ & 0.8695 & 0.0069 & $\begin{array}{l}1213-1222(0.9 \%) \\
927-1182(94.5 \%)\end{array}$ \\
\hline UOC-0032 & $14.0-14.5$ & $1049 \pm 45$ & 0.8776 & 0.0049 & $\begin{array}{l}905-1063(92.8 \%) \\
830-854(2.2 \%) \\
803-802(0.3 \%)\end{array}$ \\
\hline UOC-0033 & $14.5-15.0$ & $1233 \pm 20$ & 0.8578 & 0.0021 & $\begin{array}{l}1201-1259(39.1 \%) \\
1169-1189(14.8 \%) \\
1073-1163(41.5 \%)\end{array}$ \\
\hline
\end{tabular}


Table 1 (continued)

\begin{tabular}{|c|c|c|c|c|c|}
\hline Lab ID & Depth range $(\mathrm{cm})$ & ${ }^{14} \mathrm{C}$ age $(\mathrm{BP}) \pm 1 \sigma$ & F14C & \pm & cal yBP \\
\hline UBA-23807 & $6.5-7.0$ & $1618 \pm 25$ & & & $\begin{array}{l}1562-1475(60.3 \%) \\
1465-1414(35.1 \%)\end{array}$ \\
\hline UBA-23808 & $10.5-11.0$ & $1458 \pm 26$ & & & 1389-1303 (95.4\%) \\
\hline UBA-23809 & $20.0-20.5$ & $6015 \pm 39$ & & & $6951-6749$ (95.4\%) \\
\hline UBA-23810 & $30.0-30.5$ & $6308 \pm 45$ & & & $\begin{array}{l}7413-7396(1.1 \%) \\
7370-7360(0.5 \%) \\
7330-7158(93.08 \%)\end{array}$ \\
\hline UBA-23811 & $7.5-8.0$ & $1162 \pm 26$ & & & $\begin{array}{l}1047-1176(75.8 \%) \\
987-1031(19.6 \%)\end{array}$ \\
\hline UBA-23812 & $13.0-13.5$ & $1001 \pm 25$ & & & $\begin{array}{l}903-964(80.5 \%) \\
828-860(12.3 \%) \\
801-811(2.6 \%)\end{array}$ \\
\hline UBA-23813 & $19.5-20.0$ & $6306 \pm 33$ & & & 7167-7302 (95.4\%) \\
\hline UBA-23814 & $32.5-33.0$ & $6573 \pm 33$ & & & $\begin{array}{l}7540-7562(9.1 \%) \\
7428-7516(86.3 \%)\end{array}$ \\
\hline UBA-23815 & $43.5-44.0$ & $7492 \pm 35$ & & & $\begin{array}{l}8280-8386(68.8 \%) \\
8203-8268(26.6 \%)\end{array}$ \\
\hline
\end{tabular}

Analysis performed by A. E. Lalonde AMS Laboratories (lab ID prefix UOC) and 14 Chrono Centre (lab ID prefix UBA). Calibration was performed using OxCal 4.3 [43] and the IntCal 13 calibration curve [44]

unconformity at $\sim 17 \mathrm{~cm}$. The ash layers proved to be excellent chronostratigraphic markers as they were derived from New Year's Christmas tree bonfires that were held on the lake in 1968, 1969 and 1971 (Fig. 2; Long-time Yellowknife resident Velma Sterenberg and former Yellowknife Mayor David Lovell, pers. comm. 2015). The presence of an unconformity at $17 \mathrm{~cm}$ is further supported by the radiocarbon dating results, which indicated a middle Holocene age for sediments deposited below $17 \mathrm{~cm}$ (6749-8386 yBP; Table 1, Fig. 2). This hiatus is likely attributed to a cessation in sedimentation to Frame Lake following its gradual isolation from the nearby Yellowknife Bay [28]. Based on sedimentological analysis of this same core, coupled with an assessment of available air photo imagery for Frame Lake spanning from the present to the 1930s, it has been estimated that initiation of modern era sedimentation in the lake began in 1962 [13].

The second unit (U2) extends from the sharp stratigraphic boundary at $17 \mathrm{~cm}$ down to $44 \mathrm{~cm}$ and consists of dark olive green to brown coloured, mostly fine-grained sediments with some fraction of organic matter. The lower part of U2 $(39-44 \mathrm{~cm})$ was a depositional transition period marking the change from fine-grained sediments with an organic fraction to fine-grained glacial clays of the early Holocene (Fig. 2). Unit 3 (U3) extends from $44 \mathrm{~cm}$ to the base of the core at $86 \mathrm{~cm}$ and is characterized by finegrained light beige to nearly white glacial clay (Fig. 2).

Glew cores collected throughout Frame Lake were similar in length (45-51 cm; $\mathrm{n}=6$ ), with the exception of GC-02, which was only $17 \mathrm{~cm}$ long (Figs. 1, 3; Online Resource 2; Table 2). The majority of the Glew cores were characterized by the same three stratigraphic units identified in the freeze core, with the exception of GC-02, which only contained U1 and U2 (Fig. 3). All Glew cores contained the dark organic-rich colloidal (Gyttja) of uppermost U1 [thickest in core GC-03 $(15 \mathrm{~cm})$ and thinnest in GC-04 and GC-06 $(6 \mathrm{~cm} ;$ Fig. 3)], which transitioned to the olive green/brown coloured organic mud of $\mathrm{U} 2$.

\subsection{Geochemistry}

The ICP-MS analysis of sediments from freeze core 2012$1 F R$ was characterized by As concentrations of just $8.2 \mathrm{\mu g} \mathrm{g}^{-1}$ at $60 \mathrm{~cm}$ depth, which gradually increased up core, reaching levels above $150 \mathrm{\mu g} \mathrm{g}^{-1}$ by $25 \mathrm{~cm}$ depth (Fig. 2). Peaks of As contamination (AP-1 and AP-2) were found at $15 \mathrm{~cm}\left(688 \mu \mathrm{g} \mathrm{g}^{-1} ; A P-2\right)$ and $9.5 \mathrm{~cm}\left(1538 \mu \mathrm{g} \mathrm{g}^{-1}\right.$; AP-1). There was a gradual decrease of As concentration through the uppermost sections of the core with As levels declining to $179 \mu^{-1} g^{-1}$ in the near-surface sediments at $3.5 \mathrm{~cm}$. There are other elements related to anthropogenic and mining activity with elevated concentrations within the lake basin, such as copper $(\mathrm{Cu})$, antimony (Sb), lead $(\mathrm{Pb})$, zinc $(\mathrm{Zn})$, and chromium $(\mathrm{Cr})$. These elements, along with As, are detailed in Table 3 and are compared to the measured maximum, recent average and background average concentrations found in the core, to the CCME [38] Sediment Quality Guidelines for the Protection of Aquatic Life in freshwater, which set very specific targets for these elements, including Interim Sediment Quality Guidelines (ISQG) and Probable Effect Levels (PEL). However, these other elements of concern will not be discussed further in this paper, though the full geochemical analysis of the top $60 \mathrm{~cm}$ of this core is available in Online Resource 1. 


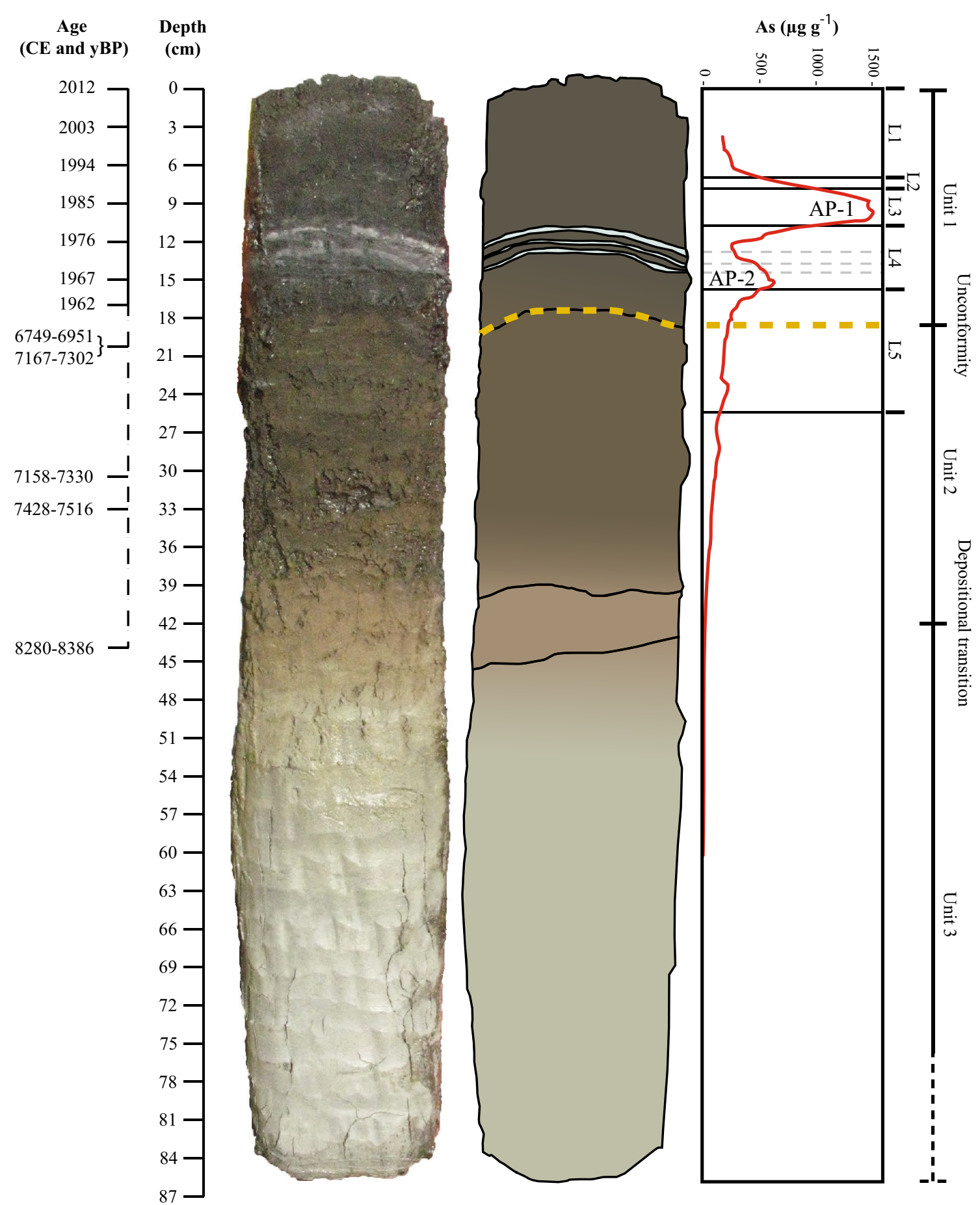

Fig. 2 Freeze core 2012-1FR (left) and its schematic view (right) showing 3 distinct stratigraphic units. Ages are marked on the far left (top ages in $C E$, bottom ages are ranges in $\mathrm{yBP}$ ), with a depth scale in $\mathrm{cm}$ to the left of the core. ICP-MS data of As concentration

\subsection{Sub-bottom profile reflector analysis}

From the results of the sub-bottom profile analysis, the upper sedimentary units (U1 and U2) could be further (from 3.5 to $60 \mathrm{~cm}$ ) is plotted on the right of the core schematic, with acoustic layers (L1-L5), stratigraphic units (U1-U3) unconformity (dark yellow dashed line on schematic) and transition area are on the far right. Modified after Gavel et al. [13]

subdivided into five layers (L1-L5) determined by the changes in sedimentary acoustic impedance, which are controlled by variation in sediment density contrast. Acoustic layers L1-L4 were contained within U1, while 
Fig. 3 Fence diagram showing the stratigraphy within Frame Lake as captured by six examined Glew cores (GC-01 to GC-06). Sampling site locations of the Glew cores are marked on Fig. 1

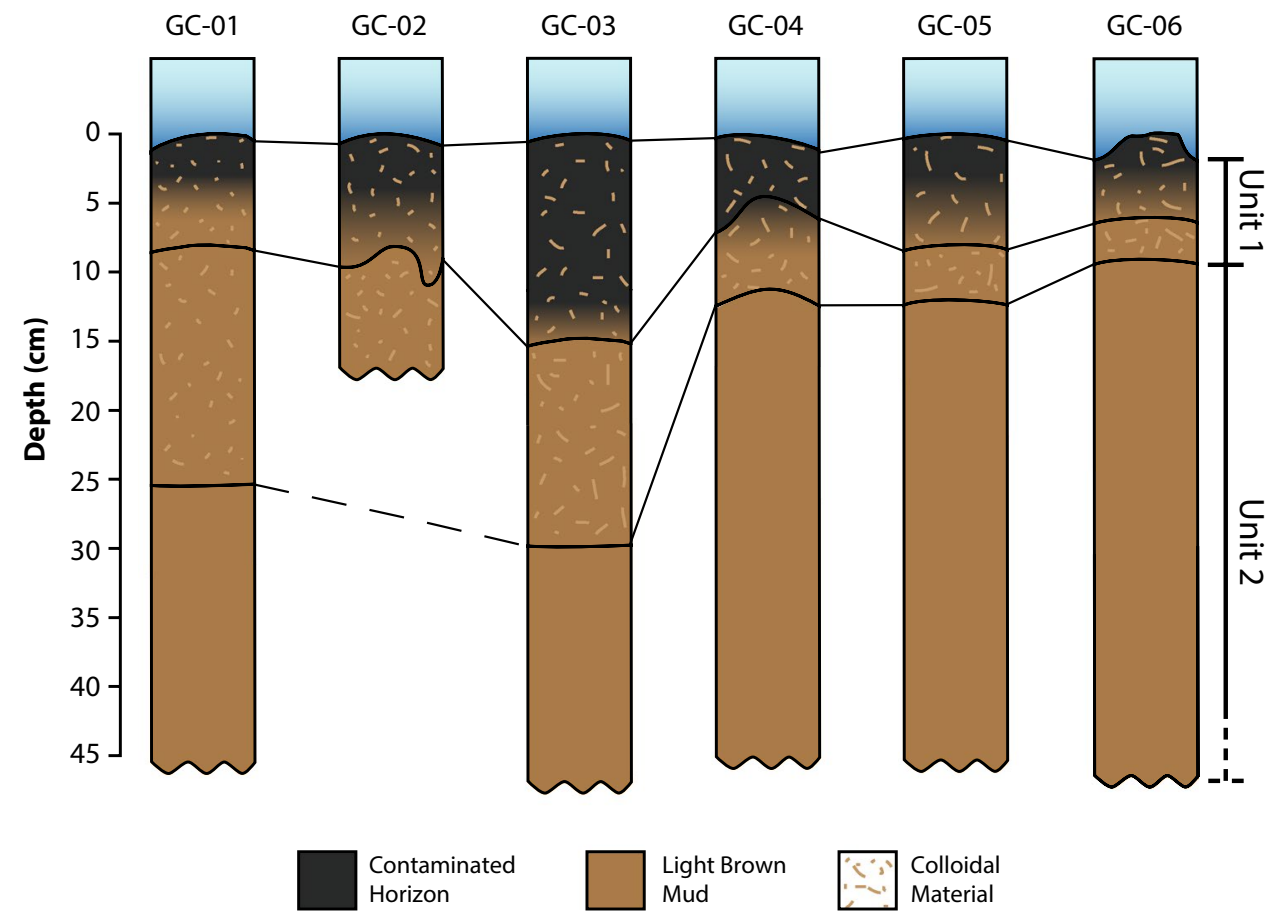

Table 2 Detailed layer thicknesses of the collected glew cores, as well as the thickness of the heavily contaminated $\left(>150 \mu \mathrm{g} \mathrm{g}^{-1}\right)$ layer U-1

\begin{tabular}{lll}
\hline Glew core ID & $\begin{array}{l}\text { Contaminated layer thickness } \\
(\mathrm{U}-1)(\mathrm{cm})\end{array}$ & $\begin{array}{l}\text { Total } \\
\text { length } \\
(\mathrm{cm})\end{array}$ \\
\hline GC-01 & 25 & 47 \\
GC-02 & 9 & 17 \\
GC-03 & 30 & 51 \\
GC-04 & 11 & 45 \\
GC-05 & 12 & 55 \\
GC-06 & 10 & 48 \\
\hline
\end{tabular}

$\mathrm{L} 5$ comprised of the lowest portion of $\mathrm{U} 1$ and the upper part of U2 (Table 4). These five acoustic layers closely correlated with distinct levels of As contamination. Acoustic L1 extended from the sediment-water interface (SWI) down to the start of the first major change in acoustic impedance, with a thickness of $\sim 5 \mathrm{~cm}( \pm 2.9 \mathrm{SD})$ and an estimated volume of $\sim 44,000 \mathrm{~m}^{3}$. Acoustic $L 2$ was delineated by the transition zone immediately below $L 1$ from low impedance to high impedance. This interval was $\sim 9.57 \mathrm{~cm}( \pm 4.8 \mathrm{SD})$ thick throughout the lake and comprised $\sim 85,000 \mathrm{~m}^{3}$ of sediment. Acoustic L3 spanned the maximum acoustic impedance recorded in Frame Lake. This unit averaged only $\sim 1.6 \mathrm{~cm}( \pm 0.8 \mathrm{SD})$ thickness with a volume of $\sim 14,000 \mathrm{~m}^{3}$ but contained the greatest concentration of highly contaminated As-bearing sediments (AP-1). Acoustic Unit L4 extended downward from the
Table 3 Concentration of elements related to anthropogenic activity as well as other elements of concern in Frame Lake, compared with Sediment Quality guidelines for the Protection of Aquatic life, Canadian Council of Ministers of the Environment, 1995

\begin{tabular}{lllcll}
\hline Element & Peak Value & Modern Average & Background level & ISQG & PEL \\
\hline As & $1538($ AP-1) & 841.83 & 16.16 & 5.90 & 17.00 \\
& $688(\mathrm{AP}-2)$ & & & & \\
$\mathrm{Cd}$ & 0.54 & 0.34 & 0.37 & 0.60 & 3.50 \\
$\mathrm{Cr}$ & 65.40 & 49.02 & 45.42 & 37.30 & 90.00 \\
$\mathrm{Cu}$ & 72.87 & 62.67 & 41.10 & 35.70 & 197.00 \\
$\mathrm{~Pb}$ & 41.66 & 31.20 & 9.41 & 35.00 & 91.30 \\
$\mathrm{Sb}$ & 28.70 & 23.87 & 0.42 & $\mathrm{~N} / \mathrm{A}$ & $\mathrm{N} / \mathrm{A}$ \\
$\mathrm{Zn}$ & 308.70 & 138.47 & 71.28 & 123.00 & 315.00 \\
\hline
\end{tabular}

The Modern average is based on top $10 \mathrm{~cm}$ of the core, while background levels are based on the average values for sediments between 40 and $60 \mathrm{~cm}$. All values are in $\mu \mathrm{g} \mathrm{g}^{-1}$ 
Table 4 Acoustic layers 1 through 5 (L1-L5) mean and maximum thicknesses, their respective calculated volumes throughout the basin and rounded values

\begin{tabular}{|c|c|c|c|c|c|}
\hline \multirow[t]{2}{*}{ Layer } & \multicolumn{4}{|l|}{ Calculated values } & \multirow[t]{2}{*}{ Rounded values } \\
\hline & $\begin{array}{l}\text { Mean thickness } \\
(\mathrm{cm})\end{array}$ & SD & $\begin{array}{l}\text { Maximum thick- } \\
\text { ness }(\mathrm{cm})\end{array}$ & Volume $\left(\mathrm{m}^{3}\right)$ & \\
\hline L1 & 5.01 & 2.85 & 10.60 & 44,259 & 44,000 \\
\hline L2 & 9.57 & 4.76 & 6.20 & 84,604 & 85,000 \\
\hline L3 & 1.62 & 0.81 & 5.00 & 14,326 & 14,000 \\
\hline L4 & 4.64 & 2.35 & 20.00 & 41,022 & 41,000 \\
\hline L5 & 5.13 & 2.50 & 25.00 & 45,331 & 45,000 \\
\hline Total & 25.96 & 10.90 & & 229,542 & 230,000 \\
\hline $150-500 \mu g^{-1}(\mathrm{~L} 1+\mathrm{L} 5)$ & & & & 89,590 & 90,000 \\
\hline $500-1000 \mu^{-1} g^{-1}(L 2+L 4)$ & & & & 125,626 & 126,000 \\
\hline$<1000 \mu \mathrm{g} \mathrm{g}^{-1}(\mathrm{~L} 3)\left(\right.$ peak $\left.1538 \mu \mathrm{g} \mathrm{g}^{-1}\right)$ & & & & 14,326 & 14,000 \\
\hline
\end{tabular}

L3 includes the peak As concentration measured in the core (AP-1, $1538 \mu \mathrm{g} \mathrm{g}^{-1}$ ) and L4 includes the second peak As level measured (AP-2, $688 \mathrm{\mu g} \mathrm{g}^{-1}$ ). For practicality and ease of use, all calculated values are reported in text rounded to 2 significant figures

peak of the maximum acoustic impedance recorded in L3 to the base of a lower impedance peak. The L4 interval had a mean thickness of $\sim 4.64 \mathrm{~cm}( \pm 2.4$ SD) with a sediment volume of $\sim 41,000 \mathrm{~m}^{3}$ and included the second isolated As peak AP-2, which formed a strong reflector throughout the entire Frame Lake basin and was characterized by high As levels (up to $688 \mu \mathrm{g} \mathrm{g}^{-1}$ ). Acoustic $L 5$ is defined as the transition from the base of AP-2 downward to the stratigraphic region of low to very low impedance (Fig. 4). The L5 unit had a mean thickness
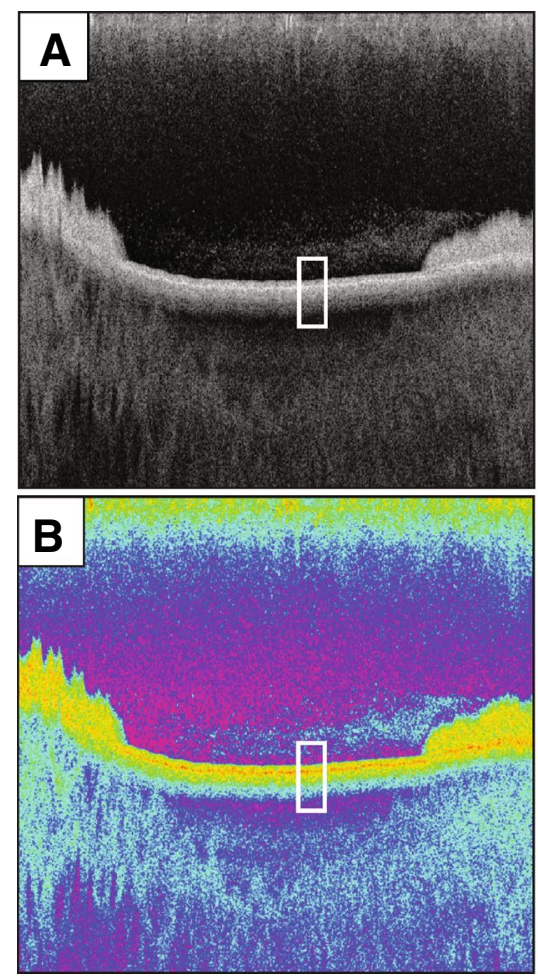
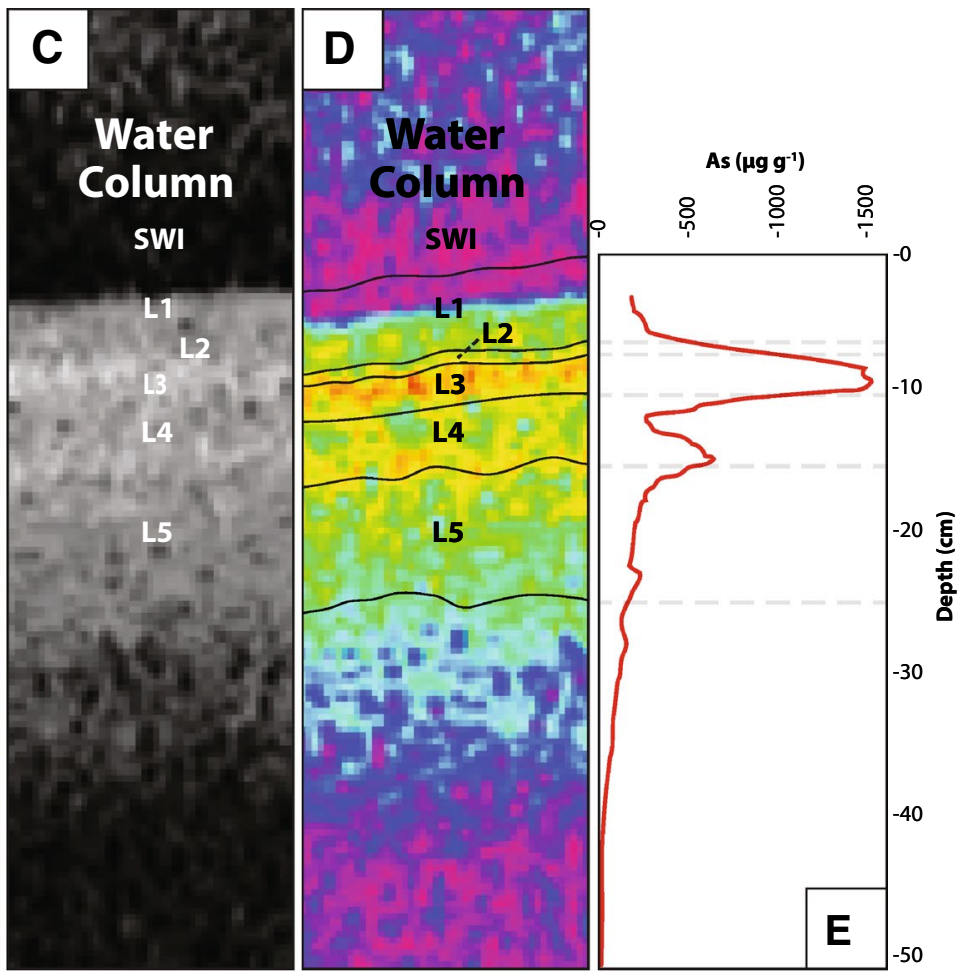

Fig. 4 Sub-bottom profile data as seen using SonarTRX software in both Graytones $(\mathbf{a}, \mathbf{c})$ and Spectrum $(\mathbf{b}, \mathbf{d})$ color schemes. $\mathbf{a}, \mathbf{b}$ show a section of the Sonar transect of Frame Lake's Southern basin. $\mathbf{c}, \mathbf{d}$ are close up views of the Sonar data (outlined in a box), highlights of acoustic layers 1 through 5 (L1, L2, L3, L4, L5) showing differ- ent reflectivity characteristics due to high levels of As and metalloid concentration. e Graphed As concentration curve from data acquired by ICP-MS analysis of freeze core 2012-1FR, with acoustic layers L1-L5 marked with grey dashed lines

\section{SN Applied Sciences}


of $\sim 5.1 \mathrm{~cm}( \pm 2.5 \mathrm{SD})$ and contained $\sim 45,000 \mathrm{~m}^{3}$ of sediment.

Both $\mathrm{L} 1$ and $\mathrm{L} 5$ were characterized by sediments with As concentrations between 150 and $500 \mathrm{\mu g} \mathrm{g}^{-1}$, which included sediments of the top $6.5 \mathrm{~cm}(\mathrm{~L} 1 ; \mathrm{U} 1)$ and those between 15.5 and $25 \mathrm{~cm}$ (U1 and $\mathrm{U} 2 ; \mathrm{L} 5$ ) at the freeze core site. The As concentrations in L2 and L4 varied from 500 to $1000 \mathrm{\mu g} \mathrm{g}^{-1}$ and at the freeze core consisted of sediments found between 6.5 to $7 \mathrm{~cm}(\mathrm{~L} 2 ; \mathrm{U} 1)$ and 10.5 to $15.5 \mathrm{~cm}(\mathrm{~L} 4 ; \mathrm{U} 1)$. L3 was associated with As concentrations $>1,000 \mu \mathrm{g} \mathrm{g}^{-1}$ (up to $1538 \mu \mathrm{g} \mathrm{g}^{-1}$ ) and includes sediments between 7 and $10.5 \mathrm{~cm}$ at the freeze core site (U1).

\subsection{Interpolation, thickness and volume estimation of the contaminated horizon}

Results of the IDW interpolation of L1-L5 across the Frame Lake basin revealed distinct landscape and stratigraphic spatial patterns with a total mean thickness of $26 \mathrm{~cm}$ ( \pm 10.9 SD; Fig. 5). Acoustic L1 tended to be thicker away from the shore with the thickest interval recorded being within Frame Lake's southern basin $(\mathrm{Max}=10.6 \mathrm{~cm})$ and, to a lesser extent, in parts of the northern basin $(\max =10 \mathrm{~cm}$;
Fig. 5-L1). Acoustic L2 had a similar distribution to that of L1, though its maximum thickness of $6.2 \mathrm{~cm}$ was more discretely distributed between the two basins (Fig. 5-L2). Acoustic L3, characterized by the highest As concentrations in the lake, was relatively evenly distributed throughout the lake with the exception of the lake's northern and western shores where a maximum thickness of $5 \mathrm{~cm}$ for this unit was found (Fig. 5-L3). Acoustic L4 was thickest along the western part of the northern basin of the lake, with a maximum thickness of $20 \mathrm{~cm}$ (Fig. 5-L4). Acoustic $\mathrm{L} 5 \mathrm{had}$ a similar distribution to that of $\mathrm{L} 4$, though with a more even distribution along the northern margin of the lake (maximum thickness $=25 \mathrm{~cm}$ ). Acoustic L3, L4, and L5 contained the bulk of the contaminated sediments and formed a package up to $50 \mathrm{~cm}$ thick along the northern and western shores of Frame Lake (Fig. 4a). Collectively, the combined thickness of all layers (L1-L5) in this region reached $57 \mathrm{~cm}$, the thickest accumulation of contaminated sediment in the lake. Based on the results of the IDW analysis the total volume of As-contaminated sediment $\left(>150 \mu \mathrm{g} \mathrm{g}^{-1}\right)$ found in L1-L5 was calculated as being $229,542 \mathrm{~m}^{3}$ (Table 4). Since the total thickness of contaminated sediment was measured at every location, and this
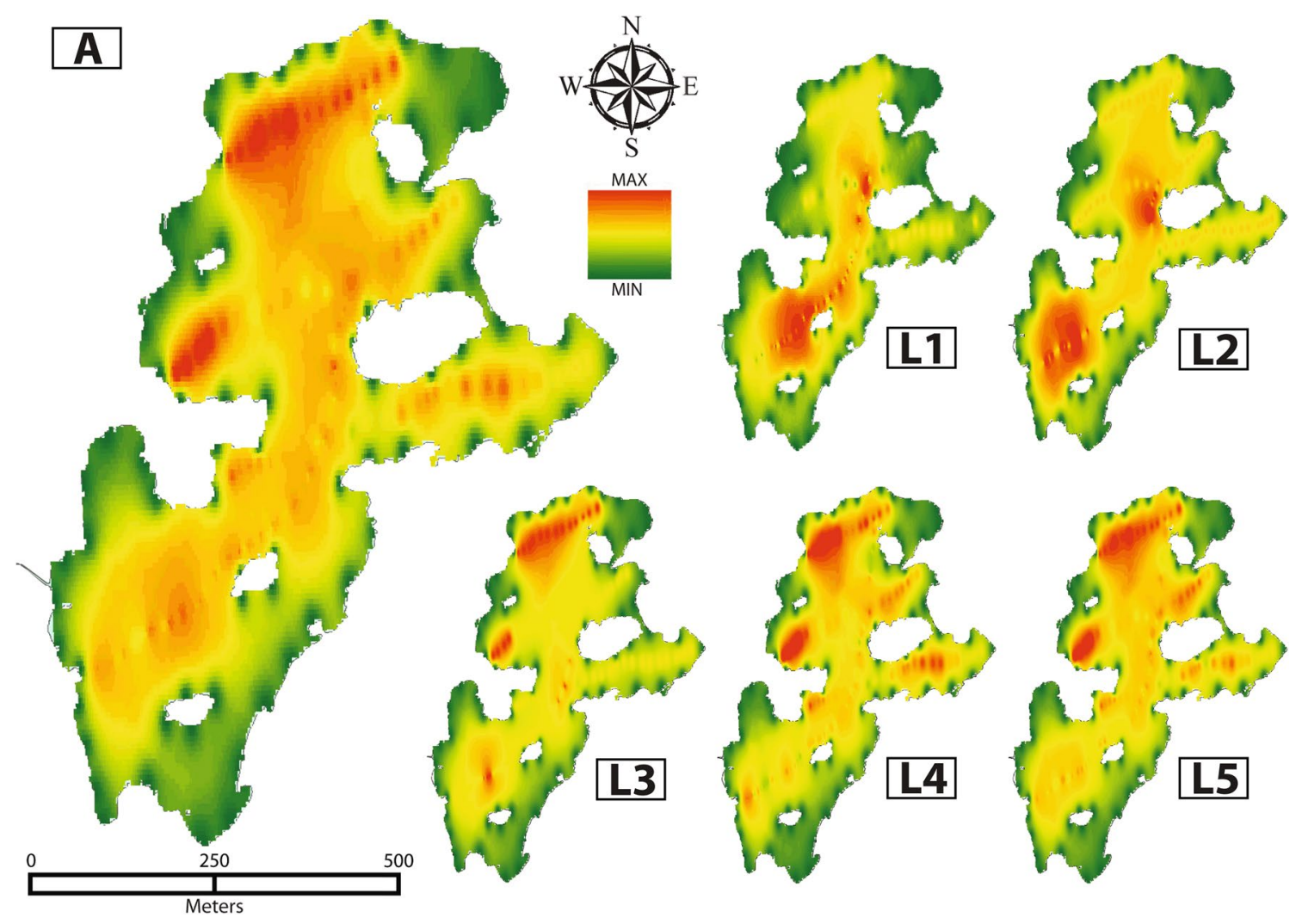

Fig. 5 IDW interpolation of the thickness of the As-contaminate sediments across Frame Lake. a IDW Interpolated map of the total thickness of As contaminated sediments $\left(>150 \mu \mathrm{g} \mathrm{g}^{-1}\right)$ L1-L5 are IDW interpolated maps of As contaminated sediments as shown

in Fig. 1 and outlined in Fig. 4. L1 has a maximum thickness of $10.6 \mathrm{~cm}$. L2 has a maximum thickness of $6.2 \mathrm{~cm}$. L3 has a maximum thickness of $5.0 \mathrm{~cm}$. L4 has a maximum thickness of $20.0 \mathrm{~cm}$. L5 has a maximum thickness of $25.0 \mathrm{~cm}$ 
overall thickness itself would be subject to the calculated $3.8 \%$ error in measurement, it is reasonable to assume that the total volume of contaminated sediment would have an error based on the total package thickness, and not an accumulation of the measurement error for all packages. Following this approach the conservative estimate for the volume of As-contaminated sediment in Frame Lake is $\sim 230,000 \pm 8700 \mathrm{~m}^{3}$ (Table 4).

\section{Discussion}

Frame Lake's health and its ability to sustain aquatic life has been in question since at least the early 1970s and provides a precautionary example of what can happen if too little is done to protect our natural resources. Conventional stratigraphic assessment of the freeze core resulted in the identification of three distinct stratigraphic units (U1-U3), with U1 sediments being deposited after AD1962 and separated from the early Holocene deposits of U2 and U3 by an unconformity. The same general stratigraphic succession was observed in the Glew cores recovered from the lake (Fig. 3). Variation in the observed unit thickness from core to core was expected as the nature and characteristics of bottom sediments within Frame Lake has been shown to vary, depending on location and basin morphology [15].

\subsection{Frame lake contamination history}

The results of ICP-MS geochemical analysis of freeze core 2012-2FRF1 revealed a gradual, yet small, increase in As concentrations between U3 and U2 overlain by drastically elevated As levels in the highly contaminated U1 horizon $\left(\sim 170-1540 \mu^{-1} \mathrm{~g} \mathrm{~g}^{-1}\right)$. The elevated As concentrations are in part attributable to the historic operations of major gold mines in the Yellowknife area (e.g. Con Mine and Giant Mine; $[13,14])$.

The elevated As concentrations within U1 (179-1538 $\mathrm{g} \mathrm{g}^{-1}$ ) are represented by two peaks: a lower peak at $\sim 15 \mathrm{~cm}\left(\mathrm{AP}-2 ; 688 \mu \mathrm{g} \mathrm{g}^{-1}\right)$ and a major peak at $\sim 10 \mathrm{~cm}$ (AP-1; $1538 \mu \mathrm{g} \mathrm{g}^{-1}$; Fig. 2). The chronologic positioning of the peaks in U1 suggests that the As contamination occurred long after Giant Mine modified its on-site ore roasting processing method in response to more stringent environmental controls on As emissions ( 1980s; $[6,7])$. Based on a detailed bioindicator/geochemical analysis of this freeze core [13], it is most likely that these chronologically anomalous peaks are the result of post-depositional remobilization of As in response to changes in several environmental factors (e.g., redox conditions, $\mathrm{pH}$, and organic matter). This assessment is supported by the results of recent geochemical studies that confirm the occurrence of vertical mobilization of As through sedimentary profiles of several lakes in the Yellowknife area (e.g., [39-41]).

In addition to having elevated As levels, U1 sediments are organic-rich [13]. The deterioration of lake water quality has not only been the result of input of As from air fall and contaminated sediments. Since the 1980 s eutrophication has been a primary driver of Frame Lake hydroecology [13]. In an analysis of both the sediments and stratigraphic temporal distribution of shelled protist (Arcellinida [testate lobose amoebae]) bioindicators, Gavel et al. [13] found that the ecology of these organisms transitioned during the 1980s from an ecological state where As was the primary control on species distribution, to a system where nutrient loading was the most important contributor to assemblage composition.

\subsection{Total thickness and volume of Arsenic contaminated sediments}

Analysis and interpretation of the ICP-MS and sub-bottom profile data permitted a determination of the lateral extent and thickness of As-contaminated sediments throughout the Frame Lake basin. Sediments with As concentrations of $>150 \mu \mathrm{g} \mathrm{g}^{-1}$ could be subdivided into five distinct layers (L1-L5), which could be acoustically recognized throughout Frame Lake (Fig. 4).

The results of the IDW interpolation of the distribution of the L1-L5 reflectors throughout the lake basin provided insight into the spatial extent of As contamination of the Frame Lake sediments, as well as valuable data for determination of the volume of highly contaminated As sediment, which might possibly have to be dredged or otherwise treated as part of a future lake rehabilitation program. The results revealed a trend of increasing thickness of the contaminated substrate away from the lake shoreline, with $L 1$ and $L 2$ being thickest closer to the southern basin, and L3-L5 exhibiting maximum thickness closer to the northern and, to a lesser extent, western shorelines (Fig. 5). The increased thickness of L3-L5 in these areas of the lake may be related to unconfirmed physical dumping of contaminated sediments in close proximity to these areas. The allochthonous source of these sediments was confirmed by the mixed radiocarbon dates from these sediments, which suggests that 'old carbon' derived from elsewhere was introduced to the lake and mixed with natural lake-bed sediments. There are multiple possible sources of this sediment such as introduction to the lake from the adjacent catchment during urban development around the lake. However, the catchment is largely composed of exposed bedrock so it is unlikely that there would have been sufficient volume of sediment from this source. Another possible origin is residue from the snow dumps that were positioned on the lake during the 1960s and 
1970s, which over several years might introduce a considerable amount of sediment to the lake bed (former Yellowknife mayor, D Lovell, pers. comm. 2015). As plows removed snow from Yellowknife area streets and highways sediment would become entrained from many sources, which provides a plausible explanation for the jumbled radiocarbon dates obtained from these sediments. There are also rumors that waste material from a nearby "1000man camp" were surreptitiously dumped in the lake, as well as the accidental dumping of a significant quantity of contaminated drilling mud that was being used to shore up a foundation of a building adjacent to the lake (V. Sterenberg; former Yellowknife mayor, G. Van Tighem, pers. comm. 2015).

Regardless of the source of the contaminated sediment, the results of IDW subsurface volume analysis indicate that at least $180,000 \mathrm{~m}^{3}$ of sediment, much of it contaminated by high As levels, have been introduced to Frame Lake since sedimentation was reinitiated in $\sim 1962$. These sediments directly overlay sediments deposited during the early Holocene. Unfortunately, due to changing hydrological redox conditions in the lake, As in the sediments migrated throughout the lake substrate. As a result some of the underlying mid-Holocene sediments of $L 5$ have also become contaminated, meaning that to return Frame Lake to a locally acceptable background As level of $<150 \mathrm{\mu g} \mathrm{g}^{-1}$ a total of $\sim 230,000 \pm 8700 \mathrm{~m}^{3}$ of contaminated sediments $\left(>150 \mu \mathrm{g} \mathrm{g}^{-1} \mathrm{As}\right.$ ) would be required to be dredged from Frame Lake as part of such a rehabilitation program. A dredging program would necessarily be focused on the thickest contaminated sedimentary deposits (i.e., L3-5), as removal of these sediments would contribute most significantly toward reducing the total volume of As contamination in the lake. Although there is some analytical uncertainty associated with the technique, these data will be of considerable value to researchers and resource managers as they determine the most appropriate strategies to revitalize Frame Lake as an important recreational area for the City of Yellowknife, while the techniques used in this paper and relatively low cost of these research methods may be directly applied to other remediation projects.

\subsection{Conclusions}

Analysis of the Frame Lake sedimentary record documents the geomorphological changes that have influenced lake history, which have been driven by deglaciation, isostatic rebound, and early Holocene warming. The considerable volume of modern deposits laid down after $\sim 1962$ $\left(\sim 180,000 \mathrm{~m}^{3}\right)$ was contributed to by the many, primarily negative, factors that have resulted in the observed hydroecological changes undergone in Frame Lake through the past 60 years. These direct and indirect human impacts include: (1) the introduction of a considerable volume of allochthonous sediment to the lake basin in the years after $\sim 1962$; (2) addition of high levels of As contamination (up to $180 \mathrm{\mu g} \mathrm{g}^{-1}$ in surface sediments and $1840 \mathrm{\mu g} \mathrm{g}^{-1}$ down core), which was either derived from air fall from local mining operations, or associated with sediments introduced to the lake basin; and (3) nutrient loading associated with changes to both water inflow and outflow to the lake, notably influenced by urbanization over much of the lake catchment and the construction of a major causeway with sluice gate to control at the outlet.

The results of this research indicate that varying levels of As contamination can be correlated with five distinct acoustic markers (L1-L5) recognized during sub-bottom profiling, which in turn can be directly ground-truthed to three stratigraphic units (U1-U3). These acoustic units are characterized by distinct As concentrations $\left(\mathrm{L} 1=180-500 \mathrm{\mu g} \mathrm{g}^{-1}, 44,000 \mathrm{~m}^{3} ; \mathrm{L} 2=500-1000 \mathrm{\mu g} \mathrm{g}^{-1}\right.$, $85,000 \mathrm{~m}^{3} ; \quad L 3=1000-1532 \mu \mathrm{g} \mathrm{g} \mathrm{g}^{-1}, 14,000 \mathrm{~m}^{3}$; $\mathrm{L} 4=500-1000 \mu \mathrm{g} \mathrm{g}^{-1}, 41,000 \mathrm{~m}^{3} ; \mathrm{L} 5=150-500 \mu \mathrm{g} \mathrm{g}^{-1}$, $45,000 \mathrm{~m}^{3}$ ), which can be traced throughout the entire Frame Lake basin. Analysis of the stratigraphic record from Frame Lake indicates that the background sedimentary As levels are in the $18-25 \mu^{-1}$ gange $[13,15]$, although the generally accepted background level in the Yellowknife area is $150 \mathrm{\mu g} \mathrm{g}^{-1}$ [42]. Based on IDW analysis of the distribution of $L 1-L 5$, an estimated volume of $\sim 230,000 \mathrm{~m}^{3}$ of sediment would have to be dredged from Frame Lake to achieve a minimum concentration of $150 \mathrm{\mu g} \mathrm{g}^{-1}$ in lake sediments. Although this technique was used to calculate absolute sediment volumes, caution must be used to account for a minimum amount of error when reporting findings.

The road to recovery for Frame Lake will not be an easy one due to the complicated nature of the combined As contamination/eutrophication problems and Frame Lake's inherently fragile hydroecology. However, with educational outreach, the involvement and engagement of the Yellowknife community, and with increasing adoption of environmental stewardship, great strides can be made towards rehabilitating Frame Lake to the healthy ecosystem and recreational resource that it once was.

Acknowledgements We acknowledge Andrew L. Macumber, Braden R.B. Gregory, Michel Haché and April S. Dalton of Carleton University, and Dr. Rachel Patterson, Dr. Paul Traynor, Queen's University Belfast, for their help with sample collection at Frame Lake in 2012, and Melody Gavel for laboratory assistance. We also thank Yellowknife resident Velma Sterenberg and former Yellowknife mayors Dave Lovell and Gord Van Tighem, and other Yellowknife residents for their much-valued information on the history of Frame Lake. Funding for this project was provided by funding from a NSERC Discovery grant to RTP, a Polar Knowledge Canada grant to RTP and JMG, two grants from Tides Canada, an Entrepreneur Support (SEED) grant from the City of Yellowknife, the Royal Bank of Canada Blue Water Fund, NWT 
Cumulative Impact Monitoring Fund (CIMP), The Giant Mine Remediation Project Team, and Trout Unlimited.

\section{Compliance with ethical standards}

Conflict of interest The authors declare that they have no conflict of interest.

\section{References}

1. Silke R (2009) The operational history of mines in the Northwest Territories, Canada: an historical research project

2. Sandlos J, Keeling A (2012) Giant mine: historical summary. Memorial University of Newfoundland, St. John's

3. Mudroch A, Joshi SR, Sutherland D, Mudroch P, Dickson KM (1989) Geochemistry of sediments in the back bay and Yellowknife Bay of the Great Slave Lake. Environ Geol Water Sci $14: 35-42$

4. Jamieson HE (2014) The legacy of arsenic contamination from mining and processing refractory gold ore at Giant Mine, Yellowknife, Northwest Territories, Canada. Rev Mineral Geochem 79:533-551

5. Fawcett SE, Jamieson HE, Nordstrom DK, McCleskey RB (2015) Arsenic and antimony geochemistry of mine wastes, associated waters and sediments at the Giant Mine, Yellowknife, Northwest Territories, Canada. Appl Geochem 62:3-17

6. MacDonald DD (1997) Controlling arsenic releases to the environment in the Northwest Territories-summary; prepared for Environmental Protection, Environment Canada, Yellowknife, N.W.T. MacDonald Environmental Services Ltd., Ladysmith

7. SRK Consulting (1997) Final report-arsenic trioxide management alternatives-Giant Mine; prepared for Department of Indian Affairs and Northern Development. Steffen Robertson and Kirsten (Canada) Consulting, Inc., Vancouver

8. Galloway JM, Sanei H, Patterson RT, Mosstajiri T, Hadlari T, Falck $H$ (2012) Total arsenic concentrations of lake sediments near the City of Yellowknife, Northwest Territories. Geological Survey of Canada, Open File 7037

9. Palmer MJ, Galloway JM, Jamieson HE, Patterson RT, Falck H, Kokelj SV (2015) The concentration of arsenic in lake waters of the Yellowknife area; Northwest Territories Geological Survey, NWT Open File 2015-06

10. Galloway JM, Palmer M, Jamieson HE, Patterson RT, Nasser N, Falck H, Macumber AL, Goldsmith SA, Sanei H, Normandeau P, Hadlari T, Roe HM, Neville LA, Lemay D (2015) Geochemistry of lakes across ecozones in the Northwest Territories and implications for the distribution of arsenic in the Yellowknife region. Part 1: sediments. Geological Survey of Canada, Open File 7908. https://doi.org/10.4095/296954

11. Government of the Northwest Territories (GNWT) (2018) Environment and Natural Resources-Giant Mine Remediation Project. https://www.enr.gov.nt.ca/en/services/giant-mine-remed iation-project. Accessed 7 July 2018

12. Healey MC, Woodall WL (1973) Limnological Surveys of the seven lakes near Yellowknife, Northwest Territories. Fisheries Research Board of Canada Fresh Water Institute, Technical report 37

13. Gavel MJ, Patterson RT, Nasser NA, Galloway JM, Roe HM, Cott PA, Ellis S (2018) What killed Frame Lake? A precautionary tale for urban planners. PeerJ 6:e4850. https://doi.org/10.7717/peerj .4850

14. Dirszowsky RW, Wilson KM (2013) Supplementary report on the sedimentary record of Frame Lake, City of Yellowknife,
Northwest Territories-the FL05 Diatom Record. Report prepared for Fish Habitat Management, Western Arctic Area; Central and Arctic Region; Fisheries and Oceans Canada

15. Dirszowsky RW, Wilson KM (2016) Biogeochemical evidence of eutrophication and metal contamination of Frame Lake, City of Yellowknife, Northwest Territories, Canada. Environ Earth Sci 75:76. https://doi.org/10.1007/s12665-015-4852-2

16. Mallon M, Rendell M (2015) Saving Frame Lake: bringing swimming and fishing back to the heart of YK. Edge_YK. https:// edgenorth.ca/article/saving-frame-lake-bringing-swimmingand-fishing-back-to-the-heart-of-yk. Accessed 8 Oct 2015

17. Chemistry Consulting Group (CCG) (2014) City of Yellowknife 2015-2019 Tourism strategy, June 2014

18. Cousens BL (2000) Geochemistry of the archean Kam group, Yellowknife greenstone belt, Slave Province, Canada. Can J Geol 108:181-197

19. Henderson JB (1985) Geology of the Yellowknife - Hearne Lake area, district of Mackenzie: a segment across an Archean basin. Geological Survey of Canada, Memoir 414

20. Stubley MP (1997) Geological complication of Carp Lake area, NTS 85P and southeastern 850; EGS 1997-07, NWT Geology Division, Indian and Northern Affairs Canada, Yellowknife, scale 1:250 000

21. Siddorn JP, Cruden AR, Hauser RL, Armstrong JP, Kirkham G (2007) The Giant-Con gold deposits: preliminary integrated structural and mineralization history. In: Anglin CD, Falck H, Wright DF, Ambrose EJ (eds) Gold in the Yellowknife Greenstone Belt, Northwest Territories: Results of the EXTECH III Multidisciplinary Research Project. Geological Association of Canada, Mineral Deposits Division, St. John's, pp 213-231

22. Kerr DE, Wilson $P(2000)$ Preliminary surficial geology studies and mineral exploration considerations in the Yellowknife area, Northwest Territories. Geological Survey of Canada Current Research 2000-C3

23. Dyke AS, Prest VK (1987) Late Wisconsinan and Holocene history of the Laurentide ice sheet. Géog Phys Quatern 41(2):237-263. https://doi.org/10.7202/032681ar

24. Smith DG (1994) Glacial lake McConnell: paleogeography, age, duration, and associated river deltas, Mackenzie river basin, western Canada. Quat Sci Rev 13:829-843

25. Environment Canada (2010) National climate data and information archive, Canadian climate normals and averages 1981-2010. Environment Canada, Yellowknife A, Northwest Territories. http://www.climate.weatheroffice.gc.ca. Accessed 5 Sept 2017

26. Environment Canada (1990) National climate data and information archive, Canadian climate normals and averages 19611990. Environment Canada, Yellowknife A, Northwest Territories. http://www.climate.weatheroffice.gc.ca. Accessed 5 Sept 2017

27. Lemmen DS, Duk-Rodkin A, Bednarski JM (1994) Late glacial drainage systems along the northwest margin of the Laurentide ice sheet. Quat Sci Rev 13:805-828. https://doi. org/10.1016/0277-3791(94)90003-5

28. Wolfe SA, Morse PD (2017) Lithalsa formation and Holocene lake-level recession, Great Slave Lowland, Northwest Territories. Permafr Periglac Process 28:573-579. https://doi.org/10.1002/ ppp.1901

29. Friske PWB, Hornbrook EHW (1991) Canada's national geochemical reconnaissance programme. Trans Inst Min Metall (Sect B Appl Earth Sci) 100:B47-B56

30. Canadian Council of Ministers of the Environment (CCME) (1999) EPC-98E. Prepared by Environment Canada, Guidelines Division, Technical Secretariat of the CCME Task Group on Water Quality Guidelines, Ottawa. [Reprinted in Canadian environmental quality guidelines, Chapter 6, Canadian Council of Ministers of the Environment, 1999, Winnipeg] 
31. Risklogic (Risklogic Scientific Services Inc.; 2002) Determining Natural (Background) Arsenic soil concentrations in Yellowknife NWT and deriving site-specific human health-based remediation objectives for arsenic in the Yellowknife Area: final report

32. Moore JW, Wheeler SJ, Sutherland DJ (1978) The effects of metal mines on aquatic ecosystems in the Northwest Territories II. Giant Yellowknife Mines Limited. Northwest Region, Environment Protection Services, Fisheries and Environment Canada. Report EPS 5-NW-78-9

33. Mace IS (1998) A study of arsenic contamination from the Royal Oak Giant Mine, Yellowknife, Northwest Territories. Masters Thesis, Royal Military College of Canada

34. Nasser NA, Patterson RT, Roe HM, Galloway JM, Falck H, Palmer MJ, Spence C, Sannei H, Macumber AL, Neville LA (2016) Lacustrine Arcellinina (Testate Amoebae) as bioindicators of arsenic contamination. Microb Ecol 72:130-149. https://doi. org/10.1007/s00248-016-0752-6

35. Glew JR, Smol JP, Last WM (2001) Sediment core collection and extrusion. In: Last WM, Smol JP (eds) Tracking environmental change using lake sediments, vol 1. Basin analysis, coring, and chronological techniques. Kluwer Academic Publishers, Dordrecht, pp 73-105

36. Macumber AL, Patterson RT (2011) A sledge microtome for high resolution subsampling of freeze cores. J Paleolimnol 45:307-310

37. Dunbar JA, Allen PM, Higley PD (2000) Color-encoding multifrequency acoustic data for near-bottom studies. Geophysics 65(3):994-1002

38. Canadian Council of Ministers of the Environment (CCME) (1995) Protocol for the derivation of Canadian sediment quality guidelines for the protection of aquatic life

39. Andrade CF, Jamieson HE, Kyser TK, Praharaj T, Fortin D (2010) Biogeochemical redox cycling of arsenic in mine-impacted lake sediments and co-existing pore waters near Giant Mine, Yellowknife Bay, Canada. Appl Geochem 25:199-211

40. Van Den Berghe M (2016) Understanding arsenic mobility and speciation in lake sediments impacted by Ore Roasting Near Giant Mine, NWT. M.Sc. Thesis. Queen's University, Kingston, Ontario

41. Schuh CE, Jamieson HE, Palmer MJ, Martin AJ (2018) Solid-phase speciation and post-depositional mobility of arsenic in lake sediments impacted by ore roasting at legacy gold mines in the Yellowknife area, Northwest Territories, Canada. Appl Geochem 91:208-221

42. Galloway JM, Palmer M, Swindles GT, Jamieson HE, Parsons MB, Sanei H, Macumber AL, Patterson RT, Falck H (2018) Organic matter control on the distribution of arsenic in lake sediments impacted by $\sim 65$ years of gold ore processing in subarctic Canada. Sci Total Environ 622-623:1668-1679

43. Bronk Ramsey C, Dee M, Lee S, Nakagawa T, Staff RA (2009) Bayesian analysis of radiocarbon dates. Radiocarbon 51:337-360

44. Reimer PJ, Bard E, Bayliss A, Beck JW, Blackwell PG, Bronk Ramsey C, Buck CE, Cheng H, Edwards RL, Friedrich M, Grootes PM, Guilderson TP, Haflidason $H$, Hajdas I, Hatté C, Heaton TJ, Hogg AG, Hughen KA, Kaiser KF, Kromer B, Manning SW, Niu M, Reimer RW, Richards DA, Scott EM, Southon JR, Turney CSM, van der Plicht $\mathrm{J}$ (2013) IntCal13 and MARINE13 radiocarbon age calibration curves 0-50000 years calBP. Radiocarbon 55(4):1869-1887

Publisher's Note Springer Nature remains neutral with regard to jurisdictional claims in published maps and institutional affiliations. 